\title{
Cell encapsulation technology as a therapeutic strategy for CNS malignancies ${ }^{1}$
}

\author{
Therese Visted, ${ }^{2}$ Rolf Bjerkvig, and Per Øyvind Enger \\ Laboratory of Neuro-Oncology, Department of Anatomy and Cell Biology, University of Bergen, \\ N-5009 Bergen, Norway
}

Gene therapy using viral vectors has to date failed to reveal its definitive clinical usefulness. Cell encapsulation technology represents an alternative, nonviral approach for the delivery of biologically active compounds to tumors. This strategy involves the use of genetically engineered producer cells that secrete a protein with therapeutic potential. The cells are encapsulated in an immunoisolating material that makes them suitable for transplantation. The capsules, or bioreactors, permit the release of recombinant proteins that may assert their effects in the tumor microenvironment. During the last decades, there has been significant progress in the development of encapsulation technologies that comprise devices for both macro- and microencapsulation. The polysaccharide alginate is the most commonly used material for cell encapsulation and is well tolerated by various tissues. A wide spectrum of cells and tissues has been encapsulated and implanted, both in animals and humans, indicating the general applicability of this approach for both research and medical purposes, including CNS malignancies. Gliomas most frequently recur at the resection site. To provide local and sustained drug delivery, the bioreactors can be implanted in the brain parenchyma or in the ventricular system. The development of comprehensive analyses of geno- and phenotypic profiles of a tumor (genomics and proteomics)

Received 8 December 2000, accepted 14 March 2001.

${ }^{1}$ Supported by The Norwegian Cancer Society, The Norwegian Research Council, The University of Bergen, The National Program for Gene Therapy, and Innovest.

${ }^{2}$ Address correspondence and reprint requests to Therese Visted, Department of Anatomy and Cell Biology, University of Bergen 19, N-5019 Bergen, Norway.

${ }^{3} \mathrm{Abbreviations}$ used are as follows: CNTF, ciliary neurotrophic factor; CSF, cerebrospinal fluid; G, L-guluronic acid; hGH, human growth hormone; $M, D$-mannuronic acid. may provide new and important guidelines for choosing the optimal combination of bioreactors and recombinant proteins for therapeutic use. Neuro-Oncology 3, 201-210, 2001 (Posted to Neuro-Oncology [serial online], Doc. 00-064, May 23, 2001. URL <neuro-oncology. mc.duke.edu>)

S ince the first human gene therapy trial was initiated in 1990, an increasing number of viral gene therapy strategies have been developed targeting different malignancies (Marcel and Grausz, 1996). Even though new viral treatment strategies may have unique application areas, gene therapy has at present failed to demonstrate its definitive clinical usefulness (Puumalainen et al., 1998; Harsh et al., 2000; Warnick, 2000). Major obstacles include a limited distribution of viruses (Lang et al., 2000), low transfection efficacy (Oyvind et al., 1999; Sandmair et al., 1999), and a lack of viral specificity toward the tumor cells. An alternative strategy, used in our laboratory, involves the utilization of genetically engineered cells that secrete recombinant proteins that may interact with the tumor microenvironment (Read et al., 1999, 2001; Thorsen et al., 2000). To implant the cells, they are encapsulated in an immunoisolating substance, resulting in the formation of a bioreactor. Over the last decade, there has been substantial progress in the development of encapsulation technologies for allogeneic tissue and organ transplantation (Kühtreiber et al., 1999). This article provides an overview of different encapsulation strategies, both in preclinical and clinical use, with an emphasis on the methods for microencapsulation of cells that secrete recombinant proteins that may affect the growth of CNS malignancies.

\section{Immunoisolation Technology}

The first immunoisolation experiments were initiated as early as the 1930s (Biseeglie, 1933), but serious scientific 
interest in such technology developed in the 1970s with the encapsulation of pancreatic tissue into synthetic membranes (Chick et al., 1977; Tze and Chen, 1977). In principle, the current encapsulation systems comprise a matrix with a porous membrane. The pore size usually ranges from 5 to $200 \mathrm{~nm}$ (Martinsen et al., 1992) and ideally allows the free exchange of nutrients, oxygen, and biotherapeutic substances, whereas immunocompetent cells are excluded (Kulseng et al., 1997). The encapsulation systems comprise devices for macro- and microencapsulation. In macrocapsules, cells or tissues such as pancreatic islets can be implanted into diffusion chambers that function as arteriovenous shunts (Lanza et al., 1996). In such devices, the blood flows through the lumen of a synthetic blood vessel, with the cells localized outside the fiber. Another approach for macroencapsulation is the use of synthetic hollow fibers that are composed of tubular-shaped structures of thermoplastic material surrounding free or matrixbound cells (Renken and Hunkeler, 1998).

Macroencapsulation devices can be retrieved fairly easily and, in the case of the hollow fibers, the implantation only requires minimal invasive procedures (Aebischer et al., 1996). However, only a limited number of cells can be accommodated in these encapsulation systems, and the surface-to-volume ratio is unfavorable (Lanza et al., 1996). In the treatment of diabetes, several meters of hollow fibers are required for the implantation of sufficient pancreatic tissue to control the blood glucose level (Lacy, 1995). Another disadvantage of the macrocapsules is membrane breakage. In addition, the arteriovenous shunts are prone to blood clotting (Renken and Hunkeler, 1998).

Microcapsules have many advantages when compared with macrocapsules, including simplicity of fabrication; ease of implantation; a larger surface-to-volume ratio and cell fraction-to-volume ratio; and a wider specter of biomedical applications. In 1980, Lim and Sun reported the first successful implantation of microencapsulated tissue (Lim and Sun, 1980). They made a micro bio-organ by encapsulating islets of Langerhans in calcium alginate. After implantation in insulin-deficient rats, normoglycemia was achieved for 2 to 3 weeks. More recently, different polymers have been exploited for immunoisolation. A thorough screening of polymers for cytotoxic and cell attachment properties was performed by Wang et al. (1997). Alginate had the lowest cytotoxicity and the best cell-attachment qualities, but carboxy methylcellulose, carrageenan, and hyaluronic acid (hyaluronan) were also good candidates for microencapsulation. Alternatively, cells can be attached to the surface of small microspheres made of glass, plastics, or polysaccharides such as collagen-coated gelatin beads (Cherksey et al., 1996).

Despite the development of new polymers, Sun's classical alginate/calcium chloride capsule has been, and still is, the most important encapsulation biomaterial. The main reason for this is that animal studies and recent clinical trials suggest that alginate can provide long-term stability, biocompatibility, and viability of the transplanted cells (Laham et al., 1999; Soon-Shiong et al., 1994; Wu et al., 1989).

\section{Alginate}

Alginates are natural polysaccharides that can be isolated from brown seaweed where they represent the extracellular matrix of the organism. These compounds have had commercial applications for decades, especially in the food industry where they are used as stabilizers and thickeners, and in the pharmaceutical industry for the treatment of wounds and esophageal reflux and as sustained drug-release systems (Onsøyen, 1996). The alginate polymers consist of 2 linked anionic monomers, $G$ and $\mathrm{M}$. The polymer structure is composed of homopolymeric regions of $G$ units ( $G$ blocks) and $M$ units $^{3}$ ( $M$ blocks), interspersed with regions of mixed monomers (MG blocks). Alginate forms a gel in the presence of divalent cations, such as $\mathrm{Ca}^{2+}$, which link specifically to the $\mathrm{G}$ blocks by binding to the free carboxyl groups. A schematic model of the gel network is referred to as the egg-box model (Grant et al., 1973; Morris et al., 1978) (Fig. 1A). The $\mathrm{M}$ component is not important for the cross-linking of the alginate gel, and its contribution to the gel is not so well characterized. However, the $\mathrm{M}$ component has immunogenic properties (Otterlei et al, 1991; Kulseng et al., 1999) and it may evoke immune reactions when it is present at high concentrations (more than $85 \%$ ) in the alginate. The mechanical stability of the alginate beads is critical in the physiologic environment where divalent ions, which are involved in the network formation, are exchanged with sodium ions of the body. This results in a loosening of the G-G bonds, with a subsequent increase in porosity, swelling of the capsule, and release of the biomaterial (Thu et al., 1996a). The mechanical strength of the capsule can be raised by increasing the $\mathrm{G}$ content and the length of the $\mathrm{G}$ blocks in the alginate (Thu et al., 1996a). A second method to improve the mechanical stability is to add an outer layer of polypeptides such as poly-L-lysine (Thu et al., 1996b). Direct contact between the cytotoxic poly-L-lysine and the microenvironment can be prevented by applying an additional layer of alginate to cover the poly-Llysine/alginate capsule. The affinity of alginate for different divalent cations decreases in the following order: $\mathrm{Cd}>\mathrm{Ba}>\mathrm{Sr}>\mathrm{Ca}>\mathrm{Ni}>\mathrm{Cu}>\mathrm{Mn}$. Barium is commonly used to increase the mechanical stability, and experiments have shown that even low molar concentrations of barium in the gelling solution can substantially decrease the capsule swelling (Peirone et al., 1998; Zekorn et al., 1992). A higher mechanical stability can also be achieved by making inhomogeneous capsules. The homogeneity of the beads refers to whether the alginate is uniformly distributed throughout the capsule or whether it is concentrated in the outer part with a central cell-containing core (Fig. 1). Inhomogeneous capsules can be prepared by removing the sodium ions or by adding an osmolyte, such as mannitol, to the gelling bath (Skjak-Braek et al., 1989). Alternatively, serum proteins or medically approved perfluorocarbons can be incorporated into the gel network (Hillgärtner et al., 1999).

A variety of techniques can be used for the preparation of alginate microcapsules (Kühtreiber et al., 1999), ranging from simple handmade beads where the alginate-cell suspension is dripped into the gelling bath via 

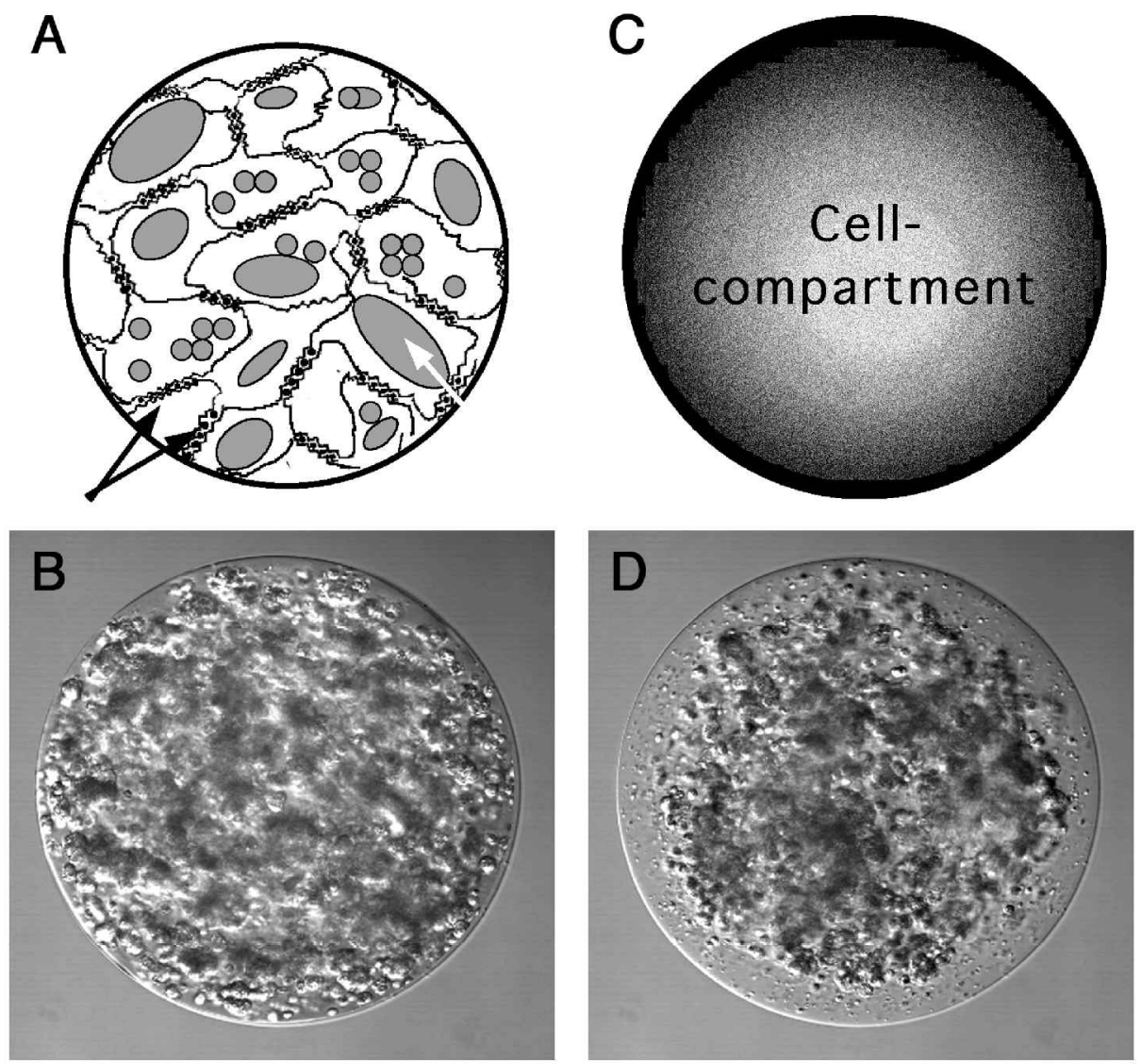

Fig. 1. Alginate microcapsules. A. Schematic model of alginate microcapsules: the "egg-box" model. G-units (black arrows) are linked by cations, forming the porous network that surrounds the producer cells (white arrow). B. Light microscopic image of a homogeneous alginate bead and producer cells $(650 \mu \mathrm{m}$ in diameter). C. Schematic model of an inhomogeneous alginate bead comprising an outer rim of alginate and an inner cell compartment. D. Light microscopic image of an inhomogeneous bead. Original magnification $\times 100$.

a syringe, to coaxial air jet or electrostatic bead generators. Some of these devices are now commercially available (http://www.nisco.ch/). In our experiments, we have used handmade microcapsules with a coaxial airstream system for size regulation (Read et al., 1999; Thorsen et al., 2000) or an electrostatic bead generator (Figs. 1, 2, and 3). The bead generator allows the production of thousands of beads per minute with a narrow size distribution. In addition, the set-up can be standardized and the size of the beads is easily adjusted by adjusting the voltage. A typical microcapsule measures 500 to $800 \mu \mathrm{m}$ in diameter, although the bead generator allows the production of microcapsules as small as $200 \mu \mathrm{m}$ in diameter.

\section{Surgical Procedures}

Transplantation of xenogeneic cells into the CNS involves different procedures that are adapted to the type of device to be implanted and the nature of the disease to be treated. In principle, they can be grouped into 2 categories, depending on whether the cells are implanted into the subarachnoid space or the brain parenchyma. From the subarachnoid space, biodistribution of neuroactive substances is mediated by CSF flow. This flow is directed from the production site in the choroid plexus of the ventricles to the arachnoid villi, where the fluid is filtrated over to the blood circulation. Transplanting the producer cells to this location can be accomplished by performing lumbar puncture, which is less invasive than methods for depositing cells in the brain parenchyma, such as craniotomy or stereotactic surgery. The risk associated with narcosis is avoided by using lumbar puncture or a stereotactic technique. Lumbar puncture can be easily performed in most instances, but is contraindicated in patients with increased intracranial pressure from an intracranial expansion. This method has been applied by Aebischer and colleagues to treat patients with chronic pain or amyotrophic lateral sclerosis, using encapsulated cells releasing catecholamines and CNTF, respectively (Aebischer et al., 1996; Buchser et al., 1996). In both trials, they used a device comprising a 5-cm-long hollow fiber membrane containing cells in a matrix and a silicon tether. The device was inserted at the L4-L5 level under local anesthesia using a Touhy needle, guide wire, and cannula. The active part, containing the producer cells, was thus situated in the CSF among the nerve roots of the cauda equina, whereas the silicone tether was sutured to the lumbodorsal fascia. In both trials, the implants were generally well tolerated, and the patients did not receive any immunosuppression. 


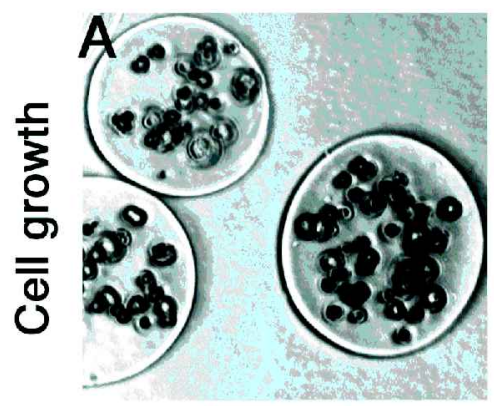

Phase 1

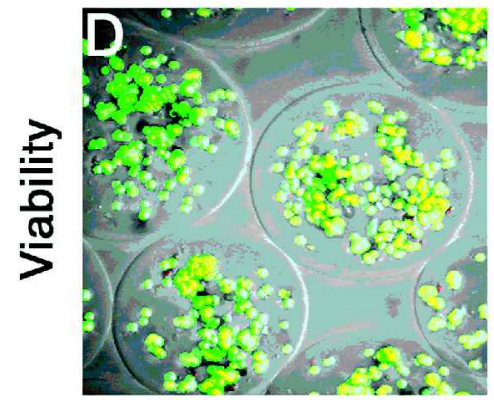

Day 1

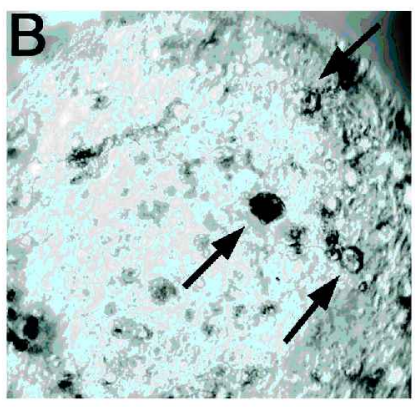

Phase 2

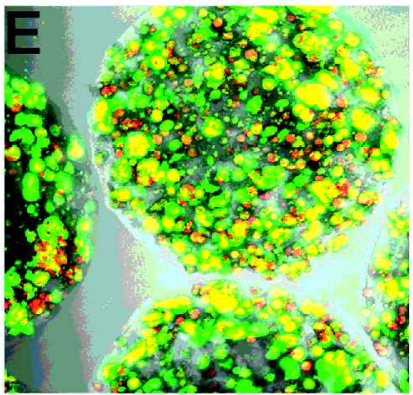

3-5 Weeks

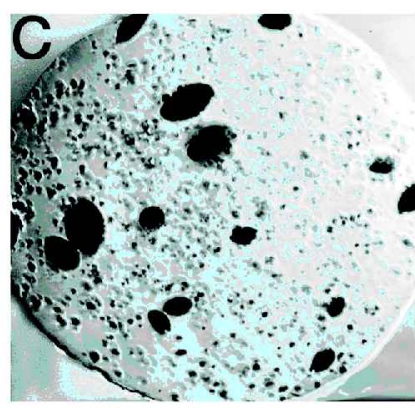

Phase 3

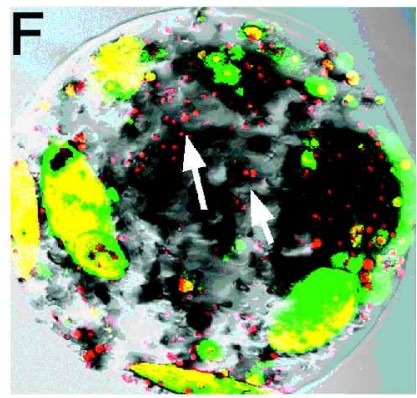

11-18 Weeks

Fig. 2. The 3 growth phases of encapsulated cells, visualized by light microscopy (A-C) and confocal imaging (D-F). Viable cells stain with calcein (green/yellow); dead cells stain red with ethidium homodimer. Viable single cells are dispersed within the bead on the first day of encapsulation ( $A$ and $D$ ). After the lag period, cells proliferate and form spheroids (B [black arrows]). In phase 3, a steady state between cell growth and death is achieved. Only cells that form spheriods seem to survive (white arrows: dying single cells). Original magnifications: $A$, $D$, and $E$ $\times 70$; $\mathrm{B} \times 90$; $\mathrm{C}$ and $\mathrm{F} \times 80$.

For other diseases, the treatment strategy will rely on local delivery, where the active substance is released in the vicinity of the target area. For diseases or lesions with a subcortical location, this involves intracerebral implantation. High local concentrations of the active substance can be provided with these systems and may be advantageous for conditions such as gliomas and Parkinson's disease. For gliomas, encapsulation devices can be implanted in the walls of the resection cavity after surgery. Transplanting cells to deep-seated areas, as in Parkinson's disease, requires a stereotactic surgical technique for optimal precision and minimal damage of nervous tissue. Even with less invasive techniques, all intracerebral implantation procedures will result in some destruction of vital tissue, and care must be taken to avoid the eloquent areas. Because intracerebral implantation involves direct contact between the brain tissue and the encapsulation device, a low immunogeneity of the implant is a fundamental premise.

\section{Biocompatibility}

Despite promising results reported in several animal experiments, limited graft survival may occur. This is attributed to host immune reactions against the implant. Zekorn et al. (1996) suggested 3 components to be considered in the evaluation of the biocompatibility of immunoisolating devices: the reaction of the encapsu- lated cells to the polymer and the method of encapsulation; the reaction of the recipient to the device (foreign body reaction); and the reaction of the recipient to the encapsulated cells and therapeutic product.

\section{Reaction of the Encapsulated Cells to the Polymer}

Successful encapsulation of bacteria, eucaryotic cells, and tissues such as islets of Langerhans has been achieved. Producer cell lines, for the treatment of experimental gliomas, show a high viability $(60 \%-90 \%)$ and maintain the secretion of the recombinant proteins for weeks after encapsulation in alginate (Read et al., 1999, 2001). Although the cells are immobilized by the matrix, they have a high proliferative activity (Peirone et al., 1998). The changes observed over time in the microcapsules emerge in 3 phases (Fig. 2). In phase 1, the lag phase, a modest cell proliferation occurs as the cells adapt to the new microenvironment. The following 2 to 3 weeks, phase 2 of the process, involve proliferation of cells and the formation of the first spheroids. Only cells that are able to form spheroids appear to survive. In phase 3, a steady state is established between cell proliferation and cell loss, which is confined to the spheroids.

\section{Reaction of the Recipient Toward the Beads}

Several reports have described how graft survival is significantly enhanced by encapsulation (Hasse et al., 1994; 
"Library" of Encapsulated Producer Cells
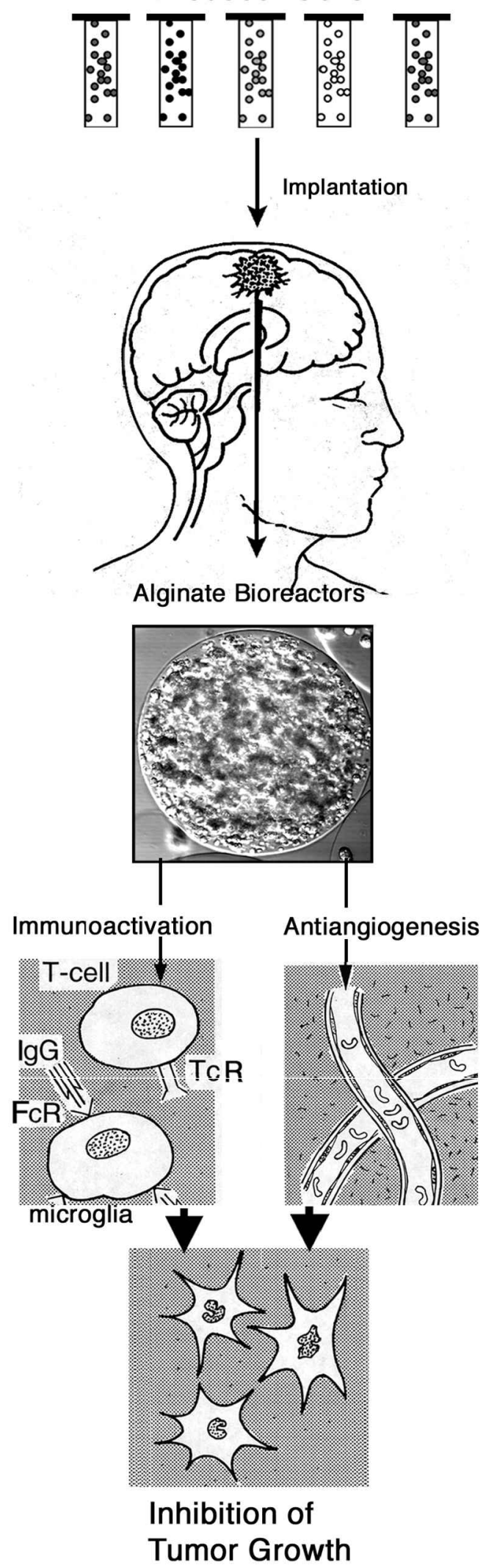

Fig. 3. Schematic presentation of the alginate concept used for the treatment of CNS malignancies.
Lanza et al., 1995; Soon-Shiong et al., 1992). However, microcapsule graft failure is often associated with fibrotic overgrowth of the capsules. As previously mentioned, a foreign body reaction has been attributed to the $\mathrm{M}$ component of the alginate, as the $\mathrm{M}$ family has strong immunogenic properties. For cell encapsulation and transplantation purposes, an alginate composition with less than $35 \%$ of $\mathrm{M}$ is considered to be most suitable (Jahr et al., 1997; Otterlei et al., 1991) and elicits only weak immune reactions in the brain (Read et al., 1999). Recent reports however, suggest that the purity of the alginate is the vital factor for successful grafting (Hasse et al., 1998; van Schilfgaarde and de Vos, 1999). Commercial alginates (not ultrapurified) have been shown to contain 20 to 30 mitogenic impurities that can elicit fibroblast activation (Zimmermann et al., 1992). G-rich (M-poor) and ultrapure/amitogenic alginate, with a controllable level of pyrogeneity (endotoxin levels below $4 \mathrm{U}$ ), is at present commercially available (http://www. pronovabiomedical.com/).

\section{Reaction of the Recipient Against the Encapsulated Cells}

Immunoisolating devices prevent monocytes and lymphocytes from destroying the encapsulated producer cells, but immune reactions against the implant are not totally abolished. Several cases report that the host produces immunoglobulins against the encapsulated material as well as the secreted recombinant proteins (Hortelano et al., 1996; Siebers et al., 1999). The host's tolerance to xenografts of encapsulated biomaterial also appears to vary between species (Weber et al., 1995). Therefore, if specific microcapsules are well tolerated in small animals, testing in large animal models is a prerequisite before clinical application.

The location of the implant may be important to circumvent the host's immune response. The CNS may actually represent a suitable site for implantation because of its specific immunologic status. The immune responses in the CNS are mainly cellular, and the alginate provides a barrier against cell-mediated (lymphocytes, natural killer cells, or microglia) destruction of the producer cells. Because the idea of using microcapsules for the treatment of diseases in the CNS is novel, only limited information is available on the parenchymal reaction to the microcapsules. The alginates, with or without encapsulated producer cells, could theoretically elicit a brisk glial reaction that could abolish any therapeutic benefits. To date, no clinical trials have been performed on this issue. There is also limited information available on alginate toxicity/reactivity in the brain in large animal models. However, Read et al. (1999) have studied the immunologic responses evoked in the rat brain upon implantation of microcapsules containing 293 producer cells. Tissue sections were stained for microglia (OX42), rat macrophages, $\mathrm{T}$ cells, and $\mathrm{B}$ cells after 1,3 , and 9 weeks. A limited accumulation of mononuclear cells was observed in the parenchyma adjacent to the microcapsules after 1 week, consisting mainly of microglia and macrophages. The immune reactivity decreased during the following weeks, and the morphology of the tissue in 
the border zone did not show any evidence of a severe glial reaction (immunohistochemical staining for OX42 after 9 weeks).

\section{Biodistribution}

Several studies have reported the delivery of recombinant gene products to the CNS. Ross and colleagues (1999) used alginate beads with mouse myoblasts releasing hGH and implanted these into the right lateral ventricle of mice. In vitro analyses indicated a relative stable secretion of hGH per volume of capsules for up to 75 days postencapsulation. Quantification of hGH by a solidphase enzyme-linked immunosorbent assay was performed on homogenized tissue from several regions from both hemispheres of the brain. Significant levels were detected up to 16 weeks after implantation with a peak at 8 weeks. Highest levels were measured in brain tissue from the implantation site and in the region anterior to it, suggesting a CSF-mediated spread. In addition, the distribution of hGH was assessed using immunocytochemistry. The protein was observed in a decreasing gradient from the implantation site within an area 1.5 to $2 \mathrm{~mm}$ in diameter. Fluorescence was also detected adjacent to the left ventricle, indicating that hGH released in the ventricular space had diffused into the surrounding parenchyma.

Thorsen and colleagues (2000) studied antibody release from encapsulated hybridoma cells. In vitro release from 10 beads, each containing $1.5 \times 10^{3}$ cells, was $13 \mathrm{ng} /(\mathrm{ml} / \mathrm{h})$ at the day of encapsulation, increasing steadily to a peak of $457 \mathrm{ng} /(\mathrm{ml} / \mathrm{h})$ at 12 days. During the last 3 weeks of the observation period, the production stabilized at $400 \mathrm{ng} /(\mathrm{ml} / \mathrm{h})$. After implantation in the rat brain, immunoglobulins could be observed at a distance of $1 \mathrm{~mm}$ from the implantation site of the alginate beads. Two of the rat brains displayed antibodies in the whole hemisphere, at the side of the implantation, and also in the leptomeninges of both hemispheres.

Read et al. (2001) implemented the alginate concept in a therapeutic model where rats with brain tumors were treated with alginate beads containing human 293 cells releasing endostatin. In vitro, 10 beads released $2 \mu \mathrm{g} / \mathrm{ml}$ endostatin during a 48 -h period. In vivo, release was verified by immunocytochemistry, which showed staining in the tumor tissue as well as by Western blot analysis of CSF samples. The prolonged survival observed in the intervention group suggests that the biodistribution is also significant for therapeutic applications (Read et al., 2001).

In humans, the only source to date on biodistribution is from studies on intrathecal delivery from macroencapsulated cells. In a series of 6 patients with amyotrophic lateral sclerosis, Aebischer et al. (1996) implanted polymer capsules releasing CNTF into the lumbar space. Nanogram levels of CNTF were measured in patients' CSF for at least 17 weeks posttransplantation, whereas it was undetectable before implantation. In another study performed by Buchser et al. (1996), patients with chronic pain were implanted with similar polymers with chromaffin cells releasing catecholamines with a strong anal- gesic effect. Even though the increase in CSF concentrations of the substance was not significant in the lumbar puncture aspirates, all patients using epidural morphine decreased the intake after implantation. Capsules retrieved from some of the patients several months after implantation still showed release of catecholamines, although it had decreased from the preimplant values. From these findings, it can be concluded that the biodistribution of a recombinant protein can be maintained at a stable level for several months.

Whereas spreading within the CSF is mediated by bulk flow, distribution within the brain tissue or from CSF into brain tissue occurs by diffusion. However, some fundamental aspects concerning the nature of these processes should be noted: First, the spread of a biologically active substance by CSF flow is directional from the choroid plexus of the lateral ventricles to the subarachnoid space surrounding the brain and the spinal cord. Thus, at least for some neurologic diseases, the site of release should be upstream to the target area.

Second, diffusion is a slow process, and the time required to move a distance by diffusion is proportional to the square of the distance. Also, the substance released from the producer cells will have an exponentially declining concentration away from the beads. Therefore, an extensive infiltration of the target volume with the implants releasing the active substance will be required to reach therapeutic levels of the compound, especially for substances with a short half life.

\section{Animal Experiments and Clinical Trials}

Macrocapsules as well as microcapsules have been applied in a variety of animal models in vivo, and the number of clinical trials is also increasing (Tables 1 and 2 ). Several investigators have reported alleviations of symptoms of experimental parkinsonism in rats by implanting different devices with dopamine-releasing cells (Aebischer et al., 1991; Lindner et al., 1997). In a monkey model of Huntington's diseases, CNTF released from encapsulated baby hamster kidney cells reduced the extent of striatal damage (Emerich et al., 1997). Neural growth factors released from encapsulated cells have also been shown to slow down degeneration of motor neurons in different rodent models of amyotrophic lateral sclerosis (Sendtner et al., 1992) and to promote survival of axotomized septal cholinergic neurons (Winn et al., 1994).

The experience and results achieved from animal experiments have provided a scientific basis for several clinical trials. Soon-Shiong et al. (1994) implanted encapsulated islets intraperitoneally in a diabetic patient and detected insulin independence after 9 months. Others have applied encapsulated cells, installed intra-arterially, for the treatment of patients with advanced-stage pancreatic carcinoma (Løhr et al., 1999).

Intrathecal delivery from macroencapsulated cells, as reported in patients with amyotrophic lateral sclerosis and chronic pain, demonstrates the potential for treating other CNS diseases using this technology. A clinical protocol for the enrollment of patients with Huntington's 
Table 1. Overview of some studies using encapsulated cells to treat neurologic diseases

\begin{tabular}{lccccc} 
Author & Disease & Encapsulation & Cell line & Protein & Outcome \\
\hline Read et al., 2001 & Gliomas in rat & Microencapsulation & 293 & Endostatin & Prolonged survival \\
Emerich et al., 1997 & Huntington's disease & Microencapsulation & BHK & CNTF & Reduced neuronal loss \\
Mitsumoto et al., 1994 & Amyotrophic lateral sclerosis & Microencapsulation & BHK & CNTF & Prolonged survival \\
Winn et al., 1989 & Parkinson's disease & $\begin{array}{c}\text { Microencapsulation } \\
\text { and macroencapsulation }\end{array}$ & PC 12 & Dopamine & Reduced rotation \\
behavior & & & & beher \\
\hline
\end{tabular}

Abbreviation: BHK, baby hamster kidney.

disease into a treatment with encapsulated CNTF-releasing cells has been recently published (Bachoud-Levi et al., 2000). This treatment includes the implantation of $2.5-\mathrm{cm}$-long implants into the ventricles.

As previously described, Thorsen et al. (2000) showed that alginate beads provide a potent local delivery system of recombinant proteins to the brain, and they proposed this as a strategy for the treatment of cerebral malignancies. Since neovascularization is a hallmark of malignant gliomas and a prerequisite for neoplastic growth, angiogenesis inhibitors may suppress tumor growth by abolishing an adequate blood supply. This approach was used by Read and colleagues (2001), who reported that rats with brain tumors implanted with endostatin-releasing beads lived significantly longer than untreated controls. Sectioning of the brains from treated animals revealed reduced vessel density and large necrotic areas in the vicinity of the beads; these changes were absent in the controls. Others have made similar findings, reporting inhibition of subcutaneous glioblastoma xenografts from endostatin-releasing encapsulated cells (Joki et al., 2001).

Applications of biodegradable polymers have also demonstrated an interstitial distribution of biologically active substances, and a therapeutic potential of local delivery systems has been demonstrated both in preclinical and clinical trials (Brem et al., 1995; Fung et al., 1998; Tamargo et al., 1993; Valtonen et al., 1997). Incorporation of cytotoxic drugs into biodegradable polymers provides a sustained release of chemotherapeutic agents in the resection cavity, thereby obtaining a prolonged high exposure to remnant tumor tissue. Prospective, randomized, placebo-controlled trials have shown longer survival when carmustine-loaded polymers were used as an initial treatment for malignant gliomas (Valtonen et al., 1997) or for patients with recurrent gliomas (Brem et al., 1995). Encapsulated cells, however, still have not been applied in any trial that included patients with malignant gliomas. Despite the lack of clinical data, this technology has certain unique characteristics that make it an attractive candidate for the treatment of glioma patients. The continuous production of the active substance by producer cells may provide high local tissue concentrations, even of substances with a short biological half life (Read et al., 2001). Also, gene expression in the producer cells can be regulated using regulatory elements, such as a tetracycline-responsive element. This system can reversibly down regulate gene expression in a differentiated manner, as well as turn it off completely (Gossen and Bujard, 1992).

Because most patients who have operations for glioblastomas subsequently undergo radiation therapy, encapsulated cells cannot be implanted during primary surgery. Initial trials should, for this reason, only include patients who are scheduled for re-operation due to the local recurrences or patients who have undergone radiation therapy prior to the primary operation. The encouraging data from animal experiments mentioned above give realistic hope that trials using cell encapsulation technology for patients with malignant gliomas can be started in the near future.

\section{Future Prospects}

The sequencing of the human genome is nearly completed, bringing research into the postgenomic area. In this context, cell encapsulation technology may provide us with a very potent tool to translate new knowledge into novel therapeutic strategies. On the basis of tumor biopsies from a patient, treatment may be individually tailored using genetically engineered cells that release active substances fitted to the biological profile of the tumor. This offers unique opportunities for combined regimens targeting all of the different aspects of tumor

Table 2. Overview of clinical trials applying alginate technology

\begin{tabular}{|c|c|c|c|c|c|}
\hline Author & Disease & Encapsulation & Cell line & Protein & Outcome \\
\hline Bachoud-Levi et al., 2000 & Huntington's disease & Macroencapsulation & $\mathrm{BHK}$ & CNTF & Ongoing protocol \\
\hline Løhr et al., 1999 & Pancreas cancer & Cellulose matrix & 293 & CYP2B1 & Ongoing trial \\
\hline Aebischer et al., 1996 & Amyotrofic lateral sclerosis & Macroencapsulation & $\mathrm{BHK}$ & CNTF & Sustained release \\
\hline Buchser et al., 1996 & Chronic pain & Macroencapsulation & $\begin{array}{l}\text { Adrenal cells } \\
\text { from calves }\end{array}$ & Catecholamines & Reduced pain \\
\hline Soon-Shiong et al., 1994 & Diabetes & Microencapsulation & $\begin{array}{l}\text { Langerhan's islets/ } \\
\text { fetus }\end{array}$ & Insulin & Normoglycemia \\
\hline
\end{tabular}


growth, such as proliferation, invasion, migration, and angiogenesis. Treatment centers can then access a "freeze-library" containing a variety of differently programmed cell lines and select those expressing the appropriate gene products (Fig. 3). The challenge will then be to master the combined use of a high number of biologically active substances in a clinical setting. When these factors are brought into play with a force and synchronicity exceeding that of the brain tumor itself, progress will be made.

\section{References}

Aebischer, P., Winn, S.R., Tresco, P.A., Jaeger, C.B., and Greene, L.A. (1991) Transplantation of polymer encapsulated neurotransmitter secreting cells: Effect of the encapsulation technique. J. Biomech. Eng. 113, 178-183.

Aebischer, P., Scluep, M., Deglon, N., Joseph, J.M., Hirt, L., Heyd, B., Goddard, M., Hammang, J.P., Zurn, A.D., Kato, A.C., Regli, F., and Baetge, E.E. (1996) Intrathecal delivery of CNTF using encapsulated genetically modified xenogeneic cells in amyotrophic lateral sclerosis patients. Nat. Med. 2, 696-699.

Bachoud-Levi, A.C., Deglon, N., Nguyen, J.P., Bloch, J., Bourdet, C., Winkel, L., Remy, P., Goddard, M., Lefaucheur, J.P., Brugieres, P., Baudic, S., Cesaro, P., Peschanski, M., and Aebischer, P. (2000) Neuroprotective gene therapy for Huntington's disease using a polymer encapsulated BHK cell line engineered to secrete human CNTF. Hum. Gene Ther. 11, 1723-1729.

Biseeglie, V. (1933) Über die antineoplastische Immunitat. Z. Krebsforsch. 40, 141.

Brem, H., Piantadosi, S., Burger, P.C., Walker, M., Selker, R., Vick, N.A., Black, K., Sisti, M., Brem, S., Mohr, G., Muller, P., Moravetz, R., and Schold, S.C. (1995) Placebo-controlled trial of safety and efficacy of intraoperative controlled delivery by biodegradable polymers of chemotherapy for recurrent gliomas. Lancet 345, 1008-1012.

Buchser, E., Goddard, M., Heyd, B., Joseph, J.M., Favre, J., de Tribolet, N., Lysaght, M., and Aebischer, P. (1996) Immunoisolated xenogenic chromaffin cell therapy for chronic pain: Initial clinical experience. Anesthesiology 85, 1005-1012.

Cherksey, B.D., Sapirstein, V.S., and Geraci, A.L. (1996) Adrenal chromaffin cells on microcarriers exhibit enhanced long-term functional effects when implanted into the mammalian brain. Neuroscience 75, 657-664.

Chick, W.L., Perna, J.J., Lauris, V., Low, D., Galetti, P.M., Panol, G., Whittemore, A.D., Like, A.A., Colton, C.K., and Lysaght, M.J. (1977) Artificial pancreas using living beta cells: Effects on glucose hemostasis in diabetic rats. Science 197, 780-782.

Emerich, D.F., Winn, S.R., Hantraye, P.M., Peschanski, M., Chen, E.Y., Chu, Y., McDermott, P., Baetge, E.E., and Kordower, J.H. (1997) Protective effect of encapsulated cells producing neurotrophic factor CNTF in a monkey model of Huntington's disease. Nature 386, 395-399.

Fung, L.K., Ewend, M.G., Sills, A., Sipos, E.P., Thompson, R., Watts, M., Colvin, O.M., Brem, H., and Saltzman, W.M. (1998) Pharmacokinetics of interstitial delivery of carmustine, 4-hydroperoxycyclophosphamide, and paclitaxel from a biodegradable polymer implant in the monkey brain. Cancer Res. 58, 672-684.

Gossen, M., and Bujard, H. (1992) Tight control of gene expression in mammalian cells by tetracycline-responsive promoters. Proc. Natl. Acad. Sci. U.S.A. 89, 5547-5551.

Grant, G.T., Morris, E.R., Rees, D.A., Smith, P.J.C., and Thom, D. (1973) Biological interactions between polysaccharides and divalent cations: The egg-box model. FEBS Lett. 32, 195-198.

Harsh, G.R., Deisboeck, T.S., Louis, D.N., Hilton, J., Colvin, M., Silver, J.S., Qureshi, N.H., Kracher, J., Finkelstein, D., Chiocca, E.A., and Hochberg, F.H. (2000) Thymidine kinase activation of ganciclovir in recurrent malignant gliomas: A gene-marking and neuropathological study. J. Neurosurg. 92, 804-811.
Hasse, C., Schrezenmeir, J., Stinner, B., Schark, C., Wagner, P.K., Neumann, K., and Rothmund, M. (1994) Successful allotransplantation of microencapsulated parathyroids in rats. World J. Surg. 18, 630-634.

Hasse, C., Zielke, A., Klöck, G., Schlosser, A., Barth, P., Zimmermann, U., Sitter, H., Lorenz, W., and Rothmund, M. (1998) Amitogenic alginates: Key to first clinical application of microencapsulation technology. World $J$. Surg. 22, 659-665.

Hillgärtner, M., Zimmermann, H., Mimietz, A., Jork, A., Thürmer, F., Schneider, H., Nöth, U., Hasse, C., Haase, A., Fuhr, G., Rothmund, M., and Zimmermann, U. (1999) Immunoisolation of transplants by entrapment in ${ }^{19} \mathrm{~F}$-labelled alginate: Production, biocompatibility, stability, and long-term monitoring of functional integrity. Mat.-wiss. u. Werkstofftech. 30, 783792.

Hortelano, G., Al-Hendy, A., Ofosu, F.A., and Chang, P.L. (1996) Delivery of human factor IX in mice by encapsulated recombinant myoblasts: A novel approach towards allogeneic gene therapy of hemophilia B. Blood 87 , 5095-5103.

Jahr, T.G., Ryan, L., Sundan, A., Lichenstein, H.S., Skjak-Braek, G., and Espevik, T. (1997) Induction of tumor necrosis factor production from monocytes stimulated with mannuronic acid polymers and involvement of lipopolysaccharide-binding protein, CD14, and bactericidal/permeabilityincreasing factor. Infect. Immunol. 65, 89-94.

Joki, T., Machluf, M., Atala, A., Zhu, J.H., Seyfried, N.T., Dunn, I.F., Abe, T., Carroll, R.S., and Black, P.M. (2001) Continuous release of endostatin from microencapsulated engineered cells for tumor therapy. Nat. Biotechnol. 19, 35-39.

Kühtreiber, W.M., Lanza, R.P., and Chick, W.L. (Eds.) (1999) Cell Encapsulation Technology and Therapeutics. Boston: Birkhäuser.

Kulseng, B., Thu, B., Espevik, T., and Skjak-Braek, G. (1997) Alginate polylysine microcapsules as immune barrier: Permeability of cytokines and immunoglobulins over the capsule membrane. Cell Transplant. 6, 387-394.

Kulseng, B., Skjak-Braek, G., Ryan, L., Andersson, A., King, A., Faxvaag, A., and Espevik, T. (1999) Transplantation of alginate microcapsules: Generation of antibodies against alginates and encapsulated porcine islet-like cell clusters. Transplantation 67, 978-984.

Lacy, P.E. (1995) Treating diabetes with transplanted cells. Sci. Am. 273, 5051 and 54-58.

Laham, R., Sellke, F.W., Edelman, E.R., Pearlman, J.D., Ware, J.A., Brown, D.L., Gold, J.P., and Simons, M. (1999) Local perivascular delivery of basic fibroblast growth factor in patients undergoing coronary bypass surgery: Results of a phase I randomized, double-blind, placebo-controlled trial. Circulation 100, 1865-1871.

Lang, F.F., Fuller, G.N., Prados, M., Sawaya, R., and Yung, W.K.A. (2000) Preliminary results of a phase I clinical trial of adenovirus-mediated p53 gene therapy for recurrent glioma: Biological studies. Neuro-Oncology [serial online], Doc. 00-D129, September 21, 2000. URL: http://neuro-oncology. mc.duke.edu. Neuro-Oncology 2, 277. (Abstract)

Lanza, R.P., Kuhtreiber, W.M., Ecker, D.M., Marsh, J.P., and Chick, W.L. (1995) Transplantation of porcine and bovine islets into mice without immunosuppression using uncoated alginate microspheres. Transplant. Proc. 27, 3321. (Abstract) 
Lanza, R.P., Hayes, J.L., and Chick, W.L. (1996) Encapsulated cell technology. Nat. Biotechnol. 14, 1107-1111.

Lim, F., and Sun, A.M. (1980) Microencapsulated islets as bioartificial endocrine pancreas. Science 210, 908-910.

Lindner, M.D., Plone, M.A., Mullins, T.D., Winn, S.R., Chandonait, S.E., Stott, J.A., Blaney, T.J., Sherman, S.S., and Emerich, D.F. (1997) Somatic delivery of catecholamines in the striatum attenuate parkinsonian symptoms and widen the therapeutic window of oral sinemet in rats. Exp. Neurol. 145, 130-140.

Løhr, M., Bago, Z.T., Bergmeister, H., Ceijna, M., Freund, M., Gelbmann, W., Gunzburg, W.H., Jesnowski, R., Hain, J., Hauenstein, K., Henninger, W., Hoffmeyer, A., Karle, P., Kroger, J.C., Kundt, G., Liebe, S., Losert, U., Muller, P., Probst, A., Punschel, K., Renner, M., Renz, R., Saller, R., Salmons, B., Schuh, M., Schwendenwein, I., von Rombs, K., Wagner, T., Walter, I. (1999) Cell therapy using microencapsulated 293 cells transfected with a gene construct expressing CYP2B1, an ifosfamide converting enzyme, instilled intra-arterially in patients with advanced-stage pancreatic carcinoma: A phase I/II study. J. Mol. Med. 77, 393-398.

Marcel, T., and Grausz, J.D. (1996) The TMC worldwide gene therapy enrollment report. Hum. Gene Ther. 7, 2025-2046.

Martinsen, A., Storrø, I., and Skjåk-Braek, G. (1992) Alginate as immobilization material. III. Diffusional properties. Biotechnol. Bioeng. 39, 186-194.

Mitsumoto, H., Ikeda, K., Klinkosz, B., Cedarbaum, J.M., Wong, V., and Lindsay, R.M. (1994) Arrest of motor neuron disease in wobbler mice cotreated with CNTF and BDNF. Science 265, 1107-1110.

Morris, E.R., Rees, D.A., and Thom, D. (1978) Chiroptical and stochiometric evidence of a specific, primary dimerisation process in alginate gelation. Carbohydr. Res. [AU: journal title/abbrev. correct?] 66, 145-154.

Onsøyen, E. (1996) Commercial applications of alginates. Carbohydr. Eur. 14, 26-31.

Otterlei, M., Ostgaard, K., Skjak-Braek, G., Smidsrod, O., Soon-Shiong, P., and Espevik, T. (1991) Induction of cytokine production from human monocytes stimulated with alginate. J. Immunother. 10, 286-291.

Oyvind, P.E., Visted, T., Thorsen, F., Bjerkvig, R., and Lund-Johansen, M. (1999) Retroviral transfection of the lacZ gene from Liz-9 packaging cells to glioma spheroids. Int. J. Dev. Neurosci. 17, 665-672.

Peirone, M., Ross, C.J., Hortelano, G., Brash, J.L., and Chang, P.L. (1998) Encapsulation of various recombinant mammalian cell types in different al ginate microcapsules. J. Biomed. Mater. Res. 42, 587-596.

Puumalainen, A.M., Vapalahti, M., Agrawal, R.S., Kossila, M., Laukkanen, J., Lehtolainen, P., Viita, H., Paljarvi, L., Vanninen, R., and Yla-Herttuala, S. (1998) Beta-galactosidase gene transfer to human malignant glioma in vivo using replication-deficient retroviruses and adenoviruses. Hum. Gene Ther. 9, 1769-1774.

Read, T.A., Stensvaag, V., Vindenes, H., Ulvestad, E., Bjerkvig, R., and Thorsen, F. (1999) Cells encapsulated in alginate: A potential system for delivery of recombinant proteins to malignant brain tumours. Int. J. Dev. Neurosci. 17, 653-663.

Read, T.A., Sorensen, D.R., Mahesparan, R., Enger, P.Ø., Timpl, R., Olsen, B.R., Hjelstuen, M.H.B., Haraldseth, O., and Bjerkvig, R. (2001) Local endostatin treatment of gliomas administered by microencapsulated producer cells. Nat. Biotechnol. 19, 29-34.

Renken, A., and Hunkeler, D. (1998) Microencapsulation: A review of polymers and technologies with a focus on bioartificial organs. Polimery $\mathbf{4 3}$, 530-539.

Ross, C.J., Ralph, M., and Chang, P.L. (1999) Delivery of recombinant gene products to the central nervous system with nonautologous cells in alginate microcapsules. Hum. Gene Ther. 10, 49-59.

Sandmair, A.M., Loimas, S., Poptani, H., Vainio, P., Vanninen, R., Turunen, M., Tyynela, K., Vapalahti, M., and Yla-Herttuala, S. (1999) Low efficacy of gene therapy for rat BT4C malignant glioma using intra-tumoural transduction with thymidine kinase retrovirus packaging cell injections and ganciclovir treatment. Acta Neurochir. 141, 867-872.
Sendtner, M., Holtmann, B., Kolbeck, R., Thoenen, H., and Barde, Y.A. (1992) Brain-derived neurotrophic factor prevents the death of motoneurons in newborn rats after nerve section. Nature 360, 757-759.

Siebers, U., Horcher, A., Brandhorst, H., Brandhorst, D., Hering, B., Federlin, K., Bretzel, R.G., and Zekorn, T. (1999) Analysis of the cellular reaction towards microencapsulated xenogeneic islets after intraperitoneal transplantation. J. Mol. Med. 77, 215-218.

Skjak-Braek, G., Grasdalen, H., and Smidsrod, O. (1989) Inhomogeneous polysaccharide ionic gels. Carbohhydr. Polymers 10, 31-54.

Soon-Shiong, P., Feldman, E., Nelson, R., Komtebedde, J., Smidsrod, O., Skjak-Braek, G., Espevik, T., Heintz, R., and Lee, M. (1992) Successful reversal of spontaneous diabetes in dogs by intraperitoneal microencapsulated islets. Transplantation 54, 769-774.

Soon-Shiong, P., Heintz, R.E., Merideth, N., Yao, Q.X., Yao, Z., Zheng, T., Murphy, M., Moloney, M.K., Schmehl, M., Harris, M., Mendez, R., Mendez, R.G., Sanford, P.A. (1994) Insulin independence in a type 1 diabetic patient after encapsulated islet transplantation. Lancet 343, 950-951.

Tamargo, R.J., Myseros, J.S., Epstein, J.I., Yang, M.B., Chasin, M., and Brem, H. (1993) Interstitial chemotherapy of the $9 L$ gliosarcoma: Controlled release polymers for drug delivery in the brain. Cancer Res. 53, 329-333.

Thorsen, F., Read, T.A., Lund-Johansen, M., Tysnes, B.B., and Bjerkvig, R. (2000) Alginate-encapsulated producer cells: A potential new approach for the treatment of malignant brain tumors. Cell Transplant. 9, 773-783.

Thu, B., Bruheim, P., Espevik, T., Smidsrod, O., Soon-Shiong, P., and SkjakBraek, G. (1996a) Alginate polycation microcapsules. II. Some functional properties. Biomaterials 17, 1069-1079.

Thu, B., Bruheim, P., Espevik, T., Smidsrod, O., Soon-Shiong, P., and SkjakBraek, G. (1996b) Alginate polycation microcapsules. I. Interaction between alginate and polycation. Biomaterials 17, 1031-1040.

Tze, W.J., and Chen, L.M. (1977) Long-term survival of adult rat islets of langerhans in artificial capillary culture units. Diabetes 26, 185-191.

Valtonen, S., Timonen, U., Toivanen, P., Kalimo, H., Kivipelto, L., Heiskanen, O., Unsgaard, G., and Kuurne, T. (1997) Interstitial chemotherapy with carmustine-loaded polymers for high-grade gliomas: A randomized double-blind study. Neurosurgery 41, 44-48.

van Schilfgaarde, R., and de Vos, P. (1999) Factors influencing the properties and performance of microcapsules for immunoprotection of pancreatic islets. J. Mol. Med. 77, 199-205.

Wang, T., Lacik, I., Brissova, M., Anilkumar, A.V., Prokop, A., Hunkeler, D., Green, R., Shahrokhi, K., and Powers, A.C. (1997) An encapsulation system for the immunoisolation of pancreatic islets. Nat. Biotechnol. 15, 358-362.

Warnick, R.E. (2000) Phase III multicenter trial of GLI 328 HSV-TK gene therapy in newly diagnosed glioblastoma multiforme (GBM). NeuroOncology [serial online], Doc. 00-D226, September 21, 2000. URL: http://neuro-oncology.mc.duke.edu. Neuro-Oncology 2, 300. (Abstract)

Weber, C.J., Hagler, M., Konieczny, B., Chryssochoos, J., Rajotte, R., Lakkis, F., and Lowry, R. (1995) Encapsulated islet iso-, allo-, and xenografts in diabetic NOD mice. Transplant. Proc. 27, 3308-3311. (Abstract)

Winn, S.R., Wahlberg, L., Tresco, P.A., and Aebischer, P. (1989) An encapsulated dopamine-releasing polymer alleviates experimental parkinsonism in rats. Exp. Neurol. 105, 244-250.

Winn, S.R., Hammang, J.P., Emerich, D.F., Lee, A., Palmiter, R.D., and Baetge, E.E. (1994) Polymer-encapsulated cells genetically modified to secrete human nerve growth factor promote the survival of axotomized septal cholinergic neurons. Proc. Natl. Acad. Sci. U.S.A. 91, 2324-2328.

Wu, Z.G., Shi, Z.Q., Lu, Z.N., Yang, H., Shi, F.Y., Zheng, X.R., and Sun, A.M. (1989) In vitro culture and transplantation of encapsulated human fetal islets as an artificial endocrine pancreas. ASAIO Trans. 35, 736-738.

Zekorn, T., Siebers, U., Horcher, A., Schnettler, R., Klock, G., Bretzel, R.G., Zimmermann, U., and Federlin, K. (1992) Barium-alginate beads for immunoisolated transplantation of islets of Langerhans. Transplant. Proc. 
T. Visted et al.: Alginate encapsulated producer cells for the treatment of gliomas

24, 937-939. (Abstract)

Zekorn, T.D., Horcher, A., Mellert, J., Siebers, U., Altug, T.A., Emre, A., Hahn, H.J., and Federlin, K. (1996) Biocompatibility and immunology in the encapsulation of islets of Langerhans (bioartificial pancreas). Int. J. Artif. Organs 19, 251-257.
Zimmermann, U., Klock, G., Federlin, K., Hannig, K., Kowalski, M., Bretzel, R.G., Horcher, A., Entenmann, H., Sieber, U., and Zekorn, T. (1992) Production of mitogen-contamination free alginates with variable ratios of mannuronic acid to guluronic acid by free flow electrophoresis. Electrophoresis 13, 269-274. 